Article

\title{
Do Analysts Fully Reflect Information in Patents about Future Earnings?
}

\author{
Jaimin Goh ${ }^{1}$, Jaehong Lee ${ }^{2, * \mathbb{D}}$, Wonchang Hur ${ }^{1}$ and Yunchang Ju ${ }^{1}$ \\ 1 College of Business Administration, Inha University, Incheon 22212, Korea; jaimin@inha.ac.kr (J.G.); \\ wchur@inha.ac.kr (W.H.); wndbsckd1@naver.com (Y.J.) \\ 2 College of Business, Sangmyung University, Seoul 03016, Korea \\ * Correspondence: jaehong321@gmail.com
}

Received: 8 April 2019; Accepted: 14 May 2019; Published: 20 May 2019

\begin{abstract}
This study investigates the relationship between a firm's intellectual property (measured by patents) and its future business performance and information environments by focusing on financial analysts' forecasting behavior. The results show that patent citations have more influence on future profitability than patent counts and financial analysts pay more attention to firms with patent citations by showing higher followings for those firms. However, the findings also suggest that analyst forecasts do not fully reflect the implications of the effect of patent citations on future earnings and this under-valuation can mislead investors. Thus, we conclude that financial analysts 'partially' improve the information environment in terms of patent citations.
\end{abstract}

Keywords: patent citations; patent counts; business performance; analyst followings; analysts' forecasting activities

\section{Introduction}

This study investigates the relationship between the quality of a firm's intellectual property and its future business performance and information environments by focusing on financial analysts' forecasting behavior in capital market. In particular, the quality of intellectual property is measured by the number of patents cited by other firms (i.e., patent citations). Many studies have reported a positive relationship between the number of patents and the future profitability of firms [1-4], but few have carefully analyzed how financial analysts' forecasting activities affect the relationship.

In an innovation-based economy, research and development (R\&D) performance has considerable influence on a firm's sustainable growth. Due to the output of R\&D investment is stochastic, some R\&D activities are expected to foster the creation of a more valuable knowledge stock than others [5-7]. To enhance a firm's R\&D performance and the quality of its outcomes, a high level of financial investment is required, and this entails a substantial risk. Indeed, R\&D investment is one of the most important strategic decisions facing firms because R\&D consumes a large portion of financial investment without visible returns and thus involves considerable risks [7].

To finance R\&D activity, firms tend to rely more on equity financing through the stock market than on debt financing because the R\&D and patent stock is an intangible asset with little or no collateral value [8]. This dependence on the stock market leads to the question of whether a firm's $R \& D$ performance is fully reflected in the market value of the firm. Given that the financial market is a primary source of financial resources for $R \& D$ investment, this question is crucial for the survival of many technology-oriented firms.

Although the quality of a firm's patent stock is important information in evaluating its future performance, it is not clear whether it is well reflected in the process of analyst's forecasting behaviors. Analysts may face some constraints in their economic resources in evaluating patent-rich firms and 
thus their valuation can be adversely affected by the cost of analyzing information (e.g., time and effort required in valuation. Furthermore, similar to most leading indicators, patents are inherently idiosyncratic to specific industries, and some are even specific to individual firms (In recent dynamic business environments, a sizable portion of future earnings may reflect contributions of several leading indicators such as patents [1], the market shares of products [9], backlogs [10], customer satisfaction [11], web traffic [12,13], management actions [14] and order backlogs [13]. Under generally accepted accounting principles (GAAP), such leading indicators are not recognized but often disclosed in financial statements. If an economically significant portion of a firm's future earnings stems from leading indicators, then the absence of explicit information on contributions of such indicators to future earnings complicates stock valuation). These attributes raise the possibility that analysts do not fully incorporate contributions of patent activity to future earnings. Because of various uncertainties inherent in translating patent counts and patent citations into economic value, analysts may discount contributions of such indicators to future earnings. In addition, underpricing may occur if analysts are functionally fixated on current earnings without sufficiently adjusting for long-term benefits of underlying activities and processes captured by patent counts and citations. However, it is also likely that analysts may overestimate benefits of patent counts and citations. Due to a wide coverage of patent activity in the media and intense advertising efforts of some firms to promote their patent information, analysts' overpricing can arise. Stated differently, analysts may be overly optimistic about the relationship between patents and future earnings.

Using a sample of 4789 firm-year observations for the 1990-2015 period, this study documents evidence of the influence of patent citations to the future business performance and analysts' forecasting behavior. The results highlight as follows. First, we find a positive relationship between patent citations and business performance and a negative relationship between the simple patent counts and firms' profitability. Second, our paper also documents that highly cited patents give valuable information to analysts and thus patent citations improve the information environment for firms which results in the increase in the analysts' followings for firms with highly cited patents. Finally, we find that patent citations are associated with positive analysts' forecasts, whereas simple patent counts are related to negative earnings forecasts. To compare the forecasted earnings of analysts with actual earnings, analysts' forecasts do not fully reflect the effects of patents on future earnings. Specifically, the lower absolute coefficient value of patent citations and patent counts in the forecasting equation indicates analysts' under-valuation to firms with patents, representing analysts' mis-forecasting. This evidence of analysts' irrational assessment of patent information for firms' future earnings provides a better understanding of sophisticated investors' processing of successful R\&D outcomes and the extent to which analysts' efficiency may help secure equity financing for long-term investment.

The rest of this paper is organized as follows: Section 2 provides the background and develops the hypotheses. Section 3 describes the research design and the sample selection process. Section 4 presents the empirical results, and Section 5 concludes.

\section{Background and Hypotheses}

\subsection{Patent Citations and Business Performance}

Firms have various mechanisms for preventing competitors from taking advantage of their investment in knowledge capital, and the effectiveness of such mechanisms vary across firms and industries. In particular, the effectiveness of patents as a mechanism for appropriating R\&D returns is not consistent, and the net present value of R\&D investment for investing in patent protection varies across industry conditions and firm-specific factors [15]. Many studies have employed the number of successful patent applications as a proxy for R\&D performance. For example, raw number of patents is generally accepted as one of the most important indicators in comparing firms' innovation in terms of new technologies, processes, and products in the economics literature [16-22]. 
However, as in the case of most indicators, the patent measure, particularly simple patent counts (i.e., the number of patents), is subject to a long-running debate on its bias and limitations [21,23-25]. Here some representative examples include international and sectorial differences in patenting behaviors; differences in patenting between large and small firms; the identical weight given to both an important patent and an unimportant patent; and patents covering only a small part of the overall path from R\&D to innovation. All these limitations are frequently mentioned in the literature to criticize for using a simple patent count to proxy for R\&D success. In addition, the mere counting of patents at any level of aggregation may not enable leading indicators to be appropriately valued because simple patent counts assign a value of 1 to all patents by construction, whereas their true value reveals a large variance [26]. Further, there is substantial evidence that the distribution of patent counts is heavily skewed toward the low end, with a long and thin tail to the high-value side [4]. As noted in Scherer [27], such a Pareto-like distribution may not have a finite moment, and in particular, it may not have a finite variance. This clearly highlights that using patent counts as a proxy for R\&D performance may be more challenging.

Recent studies have employed patent citations as an indicator of firms' innovative performance [4-6,28-31]. In comparison to raw patent counts, patent citations reflect the qualitative aspects of patents. This information on previous patents can be traced in each patent application because each patent has to cite existing patents with similar or correlated technical claims, which is referred to as the relevant prior art [32]. More specifically, a large number of citations for a patent may indicate that the cited patent has the potential to lead technologically successful innovations over time. A heavy following by other firms in patent activity suggests substantial growth opportunities in the field and the ability of an innovation to overcome uncertainties concerning its economic outcome. It can also help patent-holding firms maintain their monopoly, particularly for pioneering firms [33]. In this regard, the patent citations for a specific patent can indicate its social value for technological communities.

Patent counts and patent citations may indicate two different aspects of the R\&D cycle, with patent counts indicating the quantitative aspects of research outcomes and patent citations showing the qualitative aspects of $R \& D$ outcomes. For example, the number of patents is related to expert opinions on the firm's technological strength, budgets, and scientific research outcomes but not to its financial performance, whereas patent citations are related to financial performance but not to budgets, expert opinions, and publication [34]. Even though a firm accumulates more patents than other firms, its sales growth rate and profitability are likely to decrease sharply, implying that patent counts do not necessarily mean an increase in financial performance. In sum, patent citations may be a better indicator of a firm's quality of intellectual property, which facilitates successful products and sustainable growth [35]. Based on the above arguments, the first hypothesis is stated as follows:

Hypothesis 1. Business performance is not related to patent counts but to patent citations.

\subsection{Patent Citations and the Information Environment}

Financial analysts are capital market intermediaries who contribute to improve the information environment through information gathering and dissemination [36]. Prior studies have shown that analysts tend to make reports on firms with (i) more information-based trading revenues and (ii) economic fundamentals conducive to a low-cost analysis [37-41]. Literature has examined the determinants of analyst reports on given firms and found that analysts tend to analyze large firms, firms including business groups, and those with superiority in profitability [38,42-44]. Because the cost of using profit-related information increases in adverse selection, if a firm's outcome decreases, then analysts are likely to be reluctant in forecasting firms with poor outcomes [42,45].

Consistently, Barth et al. [46] report that analysts spend more resources in collecting and analyzing information regarding R\&D-intensive firms since there are more opportunities to acquire trading gains by identifying mispricing of those firms. In addition, analysts complement firms' existing financial information by emphasizing on their own private information when reporting their earnings forecasts for firms with substantial intangible assets [47]. In summary, the prior literature suggests that as far as patent-rich firms 
are related to the firms' innovation and profitability, analysts show their interest on patent-rich firms by providing earnings forecasts, resulting in improvement of information environment.

Information on patents affects analyst service supply and demand. First, demand for analyst services is likely to increase. If $R \& D$ information provides less precise signals for firm value because of informational uncertainty and ambiguity induced by patents, then there may be demand for private information to complement noisy information [48]. Second, judging from suppliers' incentives, analysts are more likely to provide reports on mispriced securities through the acquisition of private information on firms with patents. Barth et al. [46] find that expected benefits of producing private information are greater for less informative accounting disclosure. In sum, if stock prices of firms with patents are less likely to reflect their fundamental value, then analysts may benefit more by following those firms. However, information on patents may force analysts to make more effort in evaluating that information [49]. The above discussion suggests that both the demand for private information and the probable benefit to analysts are greater for firms with patents. If the benefit exceeds the cost of additional work required to analyze firms with patents, then there is some incentive for analysts to cover those firms.

Given analysts' incentives to cover profitable firms, an increase in patent citations may be related to analyst followings because an increase in patent citations may indicate an increase in innovation capability, which can make incremental contributions to future financial performance. Therefore, a positive relationship between patent citations and analyst followings is expected. In addition, to the extent that following firms with patent counts provides analysts with opportunities to obtain trading commissions, analysts may still have incentives to cover such firms. Based on the above discussion, the following hypothesis is proposed:

Hypothesis 2. The number of analysts following a firm is related to patent counts and patent citations.

\subsection{Analysts' Forecasting Activities and Patent Citations}

Analysts' earnings forecasts have been shown to influence investors' expectations and are often used as a proxy for the market's beliefs. According to prior literature, analysts following R\&D-intensive firms can acquire private information directly or indirectly by closely following firms' research [50]. Specifically, they use scientific publications to estimate the productivity and profitability of the firms' R\&D investments and they tend to participate in academic conferences to communicate with researchers. Moreover, analysts following high R\&D firms often interact with industry experts and collect professional opinion on R\&D investments. In summary, analysts cover firm-specific, industry-specific, and macroeconomic developments, join in conference calls, evaluate financial reports, pursue various channels for information gathering, and interpret information that they collected to contribute to the price discovery process and support the market's beliefs. As far as analysts observe the link between firms' patent information and future earnings through their private information, their positive earnings forecasts for patent-rich firms indicate the possibility of success of R\&D investments.

Even though analysts make reports on patent-rich firms, detailed contents of patents are essential to determine the magnitude and direction of earnings forecasts for firms with patents. Since patent counts reflect quantitative aspects of R\&D activities and patent citations are related to financial performance by reflecting qualitative aspects of firms' intellectual property [34], analysts will assess expected net profit of firms with patent citations to be more positive than those with patent counts. In line with this, we propose the following hypothesis.

Hypothesis 3a. Analyst forecasts are affected by patent citations and patent counts.

On the contrary, greater information asymmetry, complexity, uncertainty, and lack of public information for patent-intensive firms can impede analysts' ability to provide informative earnings forecasts [51,52]. Previous studies have assumed the market rationality in which stock prices fully reflect available information in the market. However, some researchers have found evidence of mispricing, that is, the stock market not 
properly pricing firms. Sloan [53] and Xie [54] found that the stock market overprices the implications that accruals and discretionary accruals have an influence on future firm performance, interpreting that this overpricing comes from a market failure to recognize earnings management.

This mispricing has been applied to analyst forecasts. Several studies have shown that analysts do not fully identify implications of current firm-specific information for earnings forecasts [55,56]. O'Brien [57] and Ali et al. [58] report that financial analysts' earnings forecasts are biased to be extremely optimistic, and Amir et al. [59] and Gu and Wang [60] discover that analysts' forecast accuracy is significantly lower for R\&D-intensive firms. Lys and Sohn [61] and Abarbanell [62] conclude that financial analysts' forecasts do not sufficiently reflect value-relevant information implied in past stock returns. These empirical results imply that financial analysts' forecasts also do not provide sufficient incremental value-related information in earnings and thus that they are not likely to improve the efficiency of the stock market.

Patents are an output measure of the R\&D process and thus contain information on the success of a firm's innovation strategy [63]. Because R\&D investment is immediately expensed regardless of its success, market participants usually have little reliable and economically relevant information on $R \& D[51,52,64,65]$. Managers can communicate about the value of $R \& D$ activities through voluntary disclosures [66]. However, voluntary disclosure is unlikely to reduce the information gap between low and high R\&D-intensive firms because they are not audited and managers are unwilling to disclose information fully due to their competitors $[67,68]$. Because of this limited public information, stock market participants tend to seek private information, thereby generating some information asymmetry and disagreement in this behavior [69].

In short, several characteristics of patents impede the precise valuation of their implications for future earnings [51,52]. Patent information is often industry-specific and sometimes even firm-specific [13]. Disclosure of such information is voluntary in nature and is related to management discretion. And firms use extensive media coverage of patent awards, patent infringement litigation, and patent-licensing deals, resulting in investors' misevaluation of the contribution of patent information to future earnings. In addition, the content and presentation of this disclosure are not standardized according to established accounting principles, resulting in a cross-firm comparison of such information difficult.

These complications raise the possibility that analysts' forecasts also do not fully incorporate contributions of patents to future earnings. Because of some uncertainty inherent in estimating the contribution of patent information to value creation, analysts can discount the impact of patents on future earnings. In addition, analysts' under-valuation can occur because of their functional fixation on current earnings. They may not reflect long-term benefits of underlying activities acquired by patents but admit patent firms' current earnings at face value. In this regard, the following hypothesis is proposed:

Hypothesis $3 \mathbf{b}$. Analyst forecasts do not fully reflect earning persistence for firms with high patent citations and patent counts.

\section{Research Design and Sample Description}

\subsection{A Test of Patent Citations and Business Performance}

The first hypothesis predicts whether business performance is positively associated with patent counts and patent citations. Following Petersen [70], we have attempted clustering analyses by incorporating firm and year to control the possibility that there is a correlation within the group of residuals or that residuals do not follow the identical distribution. These clustering techniques have the advantage of calculating standard deviations that take into account the time series and cross-sectional correlations of samples, resulting in more conservative t-statistics [70]. To test this hypothesis, Equation (1) is estimated:

$$
E P S_{t+1}=\alpha_{0}+\beta_{1} A F_{t}^{t+1}+\beta_{2} A F E_{t}+\beta_{3} P A T E N T_{t}+\beta_{4} C I T E_{t}+v_{t}
$$

where 
$E P S_{t+1}=$ Earnings per share in year $t+1$;

$A F_{t}^{t+1}=$ Consensus of analyst forecasts for earnings per share for year $t+1$ issued in year $t$;

$A F E_{t}=($ EPS consensus - Actual EPS $) /$ Actual EPS;

$P A T E N T_{t}=$ Natural log of the patent stock in year $t$, the total number of patents granted thus far in year $t$;

$\mathrm{CITE}_{t}=$ Natural log of the citation stock in year $t$, the total number of citations that a firm's patent stock received thus far (year $t$ ) from other firms' patents.

Consistent with previous studies, the business performance, $E P S_{t+1}$, is defined as the earnings per share for the following year. Following Mishkin [71], Sloan [53], and Kasznik and McNichols [72], the equations include $A F_{t}^{t+1}$, the consensus of analysts' forecasts of earnings per share for year $t+$ 1 issued in year $t$, and $A F E_{t}$, earnings forecast error as measured by dividing actual EPS from the difference between EPS consensus and actual consensus. The year in which analysts' forecasts are issued is represented by the subscript, and the year targeted by analysts' forecasts is represented by the superscript. PATENT, one of the main variables of interest, is used to determine the total number of patents granted to a firm in year $t$. That is, this variable is used to count not only newly granted patents in year $t$ but also existing patents for a firm. The main variable CITE is used for the number of citations a firm's patent stock receives from other patents. The variable increases over time, and this increase is dependent mainly on how other firms' newly granted patents in year $t$ cite a firm's patents in its patent stock. As long as patents are related to future business performance, coefficients of PATENT and CITE are expected to be positive

\subsection{A Test of Patent Citations and Information Environment}

The second hypothesis predicts whether analyst followings are positively related to patent counts and patent citations. To proxy for information environment, we use analysts' coverage in year $t$. Following Petersen [70], Equation (2) is as follows:

$$
\text { COVER } R_{t}=\alpha_{0}+\beta_{1} P A T E N T_{t}+\beta_{2} \text { CITE }_{t}+\beta_{3} \operatorname{SIZE}_{t}+\beta_{4} L E V_{t}+\beta_{5} R O A_{t}+\beta_{6} \text { FIN }_{t}+\varepsilon_{t}
$$

where

COVER $R_{t}=$ The number of analysts covering a firm in year $t$;

$S I Z E_{t}=$ Ln (total assets);

$L E V_{t}=$ Total liabilities/Total assets;

$R O A_{t}=$ Net income/Total assets;

$F I N_{t}=($ Debt financing + Equity financing $) /$ Total assets.

See Equation (1) for other variable definitions.

Consistent with previous studies [73], the analyst following, COVER, is defined as the number of analysts covering a firm based on the number of analysts with annual earnings forecasts for the current fiscal year. The definitions of PATENT and CITE are identical with Equation (1). Previous studies have suggested that analysts tend to follow firms with larger information-based trading revenues, such as large firms, and economic fundamentals conducive to low-cost analyses [37,73-75]. Therefore, Equation (2) includes firm size (SIZE), the debt ratio (LEV), and external financing activity (FIN). More specifically, the analyst following is expected to be positively correlated with firm size (SIZE) and negatively correlated with the debt ratio (LEV) and external financing activity (FIN). Irvine [76] and Barth et al. [46] suggest that analysts follow firms with high profitability. Therefore, return on asset $(R O A)$ is included as a proxy for profitability, and a positive sign is predicted. In addition, industry and year dummies are included to control for differences in year and industry characteristics. 


\subsection{A Test of Analysts' Forecasting Activities on Patent Citations}

Hypothesis 3a investigates the relation between analysts' earnings forecasts and patent counts and patent citations. To test this hypothesis, Equation (3) is estimated based on the Petersen [70] model:

$$
A F_{t+1}^{t+1}=\alpha_{0}+\beta_{1} A F_{t}^{t+1}+\beta_{2} A F E_{t}+\beta_{3} P A T E N T_{t}+\beta_{4} \operatorname{CITE}_{t}+v_{t}
$$

where

$A F_{t+1}^{t+1}=$ Consensus of analyst forecasts for EPS for year $t+1$ issued in year $t+1$.

See Equation (1) for other variable definitions.

$A F_{t+1}^{t+1}$ is defined as consensus of analyst forecasts for earnings per share for year $t+1$, issued in year $t+1$. H3a predicts that $\beta_{3}$ and $\beta_{4}$ are positive. Definitions of control variables in Equation (3) follow those in Equation (1).

Hypothesis $3 b$ tests whether financial analysts fully incorporate earning persistence for firms with high patent citations and patent counts. More specifically, the hypothesis is used to test whether patent citations have a significant effect on a firm's future earnings and whether analysts fully reflect this relationship into their earnings forecasts for the firm.

Figure 1 shows the timeline for the measurement of analysts' forecast variables. In the spirit of Mishkin [71], Sloan [53], and Kasznik and McNichols [72], the analysis measures $A F_{t}^{t+1}$, the consensus of analysts' forecasts of earnings per share for year $t+1$ issued in year $t$, and $A F_{t+1}^{t+1}$, the consensus of analysts' forecasts of earnings per share for year $t+1$ issued in year $t+1$. The year in which analysts forecasts are issued is represented by the subscript, and the year targeted by analysts' forecasts is represented by the superscript. These two measures are identical in that the target of analysts' forecasts is year $t+1$. Analysts tend to revise their forecasts for year $t+1$ after $E P S_{t}$ is announced because actual earnings in year $t+1$ are dependent on current earnings.

$$
\begin{aligned}
& A F_{t+1}^{t+1}=\alpha_{0}+\beta_{1} A F_{t}^{t+1}+\beta_{2} A F E_{t}+\beta_{3} \text { PATENT }_{t}+\beta_{4} \text { CITE }_{t}+v_{t} \\
& \text { EPS }_{t+1}=\alpha_{0}^{*}+\beta_{1}^{*} A F_{t}^{t+1}+\beta_{2}^{*} A F E_{t}+\beta_{3}^{*} \text { PATENT }_{t}+\beta_{4}^{*} \text { CITE }_{t}+\varepsilon_{t}
\end{aligned}
$$

where

$A F_{t}^{t+1}=$ Consensus of analyst forecasts for earnings per share for year $t+1$ issued in year $t$;

$A F_{t+1}^{t+1}=$ Consensus of analyst forecasts for earnings per share for year $t+1$ issued in year $t+1$;

$E P S_{t}=$ Actual earnings per share for year $t$;

$A F E_{t}=($ EPS consensus - Actual EPS)/Actual EPS;

$P_{A T E N T}=$ Natural log of the patent stock at $\mathrm{t}$, the total number of patents granted thus far, in year $t$; $C I T E_{t}=$ Natural log of the citation stock in year $t$, the total number of citations of a firm's patent stock thus far (year $t$ ) from other firms' patents.

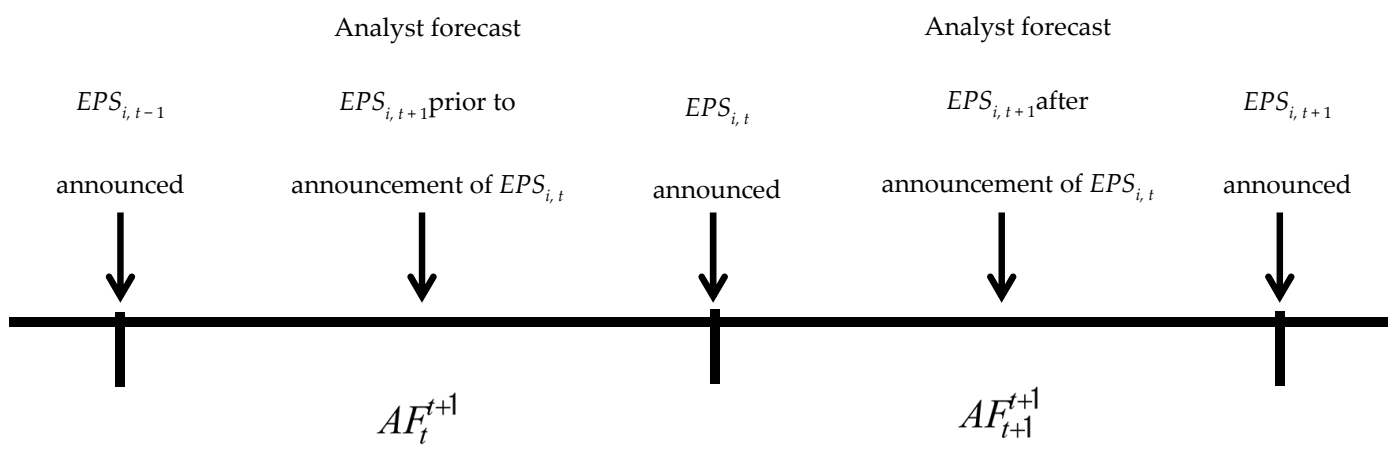

Figure 1. Timeline for the measurement of analyst forecasts. 
The first question is referred to as the "forecasting equation" because it reveals the relationship between current earnings and analysts' forecasts after the earnings announcement. On the other hand, the second equation is regarded as the "earnings equation" because it explains the relationship between current earnings and subsequent earnings. The model assumes that analysts' post-announcement forecasts are conditional on their previous forecasts for earnings of firm $i$ in year $t+1$ and on information on earnings in year $t$ relative to expectations at the beginning of year $t$. Here the earnings equation specifies that actual earnings per share in year $t+1, E P S_{t+1}$, is related to the year $t$ forecast of year $t+$ 1 earnings $A F_{t}^{t+1}$, the year $t$ earnings forecast error $A F E_{t}$, patent counts $\left(P A T E N T_{t}\right)$, and patent citations $\left(\mathrm{CITE}_{t}\right)[53,71,72]$.

More specifically, the explanatory variables in the forecasting equation are $P_{A T E N T}$ and CITE $_{t}$. According to Narin et al. [34], patent counts are related to expert opinions on a firm's technological strength, budget, and scientific research outcomes but not to those on the firm's financial performance. If analysts determine that patent counts are not related to financial performance, then the coefficient of PATENT $_{t}$ is negative.

CITE $_{t}$ is another indicator variable for a firm's patent characteristics. Information on the number of subsequent citations received by a firm's patents can be a good measure of the firm's innovation. Because citations arrive over time and can be distinguished by the identity of the citing organization, the impact of a firm's patents on its market value can be determined [5]. Therefore, a significant positive coefficient of $C I T E_{t}$ is expected based on its relationship with financial performance [34].

The research questions focus on whether analysts' post-announcement earnings forecasts fully reflect the implications of patent counts and patent citations for future earnings. Coefficients for the forecasting equation and the earnings equation are compared to assess the extent to which analysts underreact or overreact to earnings information and its relationship with firms with patents. Differences between these two coefficients are determined by jointly estimating both equations based on the seemingly unrelated regression estimation (SURE) method, which estimates the full variance-covariance matrix of estimators to enable hypothesis testing based on coefficients across equations [72].

A significant difference in these two coefficients implies analysts' mis-valuation. More specifically, even when these two coefficients have the same signs, if $\beta_{3}\left(\beta_{4}\right)$ is significantly higher than $\beta_{3}^{*}\left(\beta_{4}^{*}\right)$, then analysts are assumed to overreact to patent counts (patent citations). On the other hand, if $\beta_{3}\left(\beta_{4}\right)$ is significantly lower than $\beta_{3}^{*}\left(\beta_{4}^{*}\right)$, then analysts are assumed to underreact to patent counts (patent citations). In addition, the following case also shows analysts' mis-valuation. Suppose that the coefficients of $P A T E N T_{t}$ and $C I T E_{t}$ in both equations are negative and positive, respectively. Then a lower absolute value of the coefficient in the forecasting equation indicates analysts' underreaction to earnings, whereas a higher absolute value implies their overreaction [53,71,72].

\subsection{Sample Selection}

Observations are selected from firms listed on the New York Stock Exchange (NYSE) as of 31 December 2015. All these firms satisfy the following criteria: (1) NYSE-listed firms (except financial companies) with their accounts closing in December, (2) firms with patents granted by the USPTO (U.S. Patent and Trademark Office), (3) firms with financial statements and analysts' forecasts available in COMPUSTAT and I/B/E/S databases, and (4) firms with at least one analyst forecast value targeting the next and current years.

Here 26 years of data (1990 to 2015) satisfying the aforementioned criteria are used. Two-digit SIC codes are used as an industry indicator, and analysts' forecast accuracy exceeding $200 \%$ is eliminated (Eddy and Seifert [77] eliminate values for analyst forecasts with large forecast errors). For all relevant analyst forecasts, only those values 12 months before the earnings announcement date is used. Further, to minimize outlier effects, the top and bottom $1 \%$ of independent and dependent variables are winsorized. 


\section{Empirical Results}

\subsection{A Univariate Test}

Descriptive statistics for the variables are shown in Table 1. The mean (median) of $A F_{t}^{t+1}$ is 1.569 (1.355), and the mean (median) of $A F_{t+1}^{t+1}$ is 1.415 (1.190). In other words, analysts' post-announcement forecasts are lower than their prior forecasts for year $t+1$ earnings, indicating that analysts are less likely to over-forecast based on earnings information for year $t+1$ by adjusting current-year earnings news [72]. Actual earnings per share in year $t+1\left(E P S_{\mathrm{t}+1}\right)$ are 1.369 on average, and the fact that this value is lower than analyst forecasts for year $t$ and $t+1$ implies analysts' overreaction. And the mean (median) of the analyst following (COVER) is 1.267 (1.386), indicating that the sample firms are covered by an average of 2 additional financial analysts. The average analyst forecast error for the sample is 0.097 and the median of it is -0.001 , indicating that there is not much difference between the earnings forecasts of the financial analysts and the actual earnings. For explanatory variables, the mean (median) value of $P A T E N T_{t}$ is 0.917 (0.083), and that of CITE $E_{t}$ is 5.775 (6.009). This result indicates that patent citations are higher than simple patent counts. Consistent with the findings of previous studies, control variables show similar patterns $[5,35,72,73]$.

Table 1. Descriptive statistics.

\begin{tabular}{cccccc}
\hline Variables & Mean & STD & MIN & Median & MAX \\
\hline$A F_{t}^{t+1}$ & 1.569 & 1.058 & 0.020 & 1.355 & 5.391 \\
$A F_{t+1}^{t+1}$ & 1.415 & 1.112 & -0.681 & 1.190 & 5.599 \\
PPS $_{t+1}$ & 1.369 & 1.198 & -1.360 & 1.160 & 5.910 \\
COVER $_{t}$ & 1.267 & 0.874 & 0.000 & 1.386 & 3.091 \\
AFE & 0.097 & 1.526 & -12.294 & -0.001 & 48.868 \\
PATNT $_{t}$ & 0.917 & 2.098 & 0.000 & 0.083 & 12.007 \\
CITE & 5.775 & 2.991 & 0.000 & 6.009 & 11.804 \\
SIZE $_{t}$ & 7.488 & 1.593 & 4.309 & 7.392 & 11.477 \\
LEV $_{t}$ & 0.544 & 0.171 & 0.144 & 0.551 & 0.929 \\
ROA $_{t}$ & 0.057 & 0.065 & -0.182 & 0.057 & 0.225 \\
FIN $_{t}$ & -0.019 & 0.092 & -0.279 & -0.025 & 0.305 \\
\hline
\end{tabular}

Variable definition: $A F_{t}^{t+1}=$ Consensus of analyst forecasts for earnings per share in year $t+1$ issued in year $t$; $A F_{t+1}^{t+1}=$ Consensus of analyst forecasts for earnings per share in year $t+1$ issued in year $t+1, E P S_{t}=$ Actual earnings per share in year $t ; C O V E R_{t}=$ Natural log of the number of analysts covering a firm in year $t ; A F E_{t}=$ (EPS consensus - Actual EPS)/Actual EPS; PATENT $T_{t}=$ Natural $\log$ of the patent stock in year $t$, the total number of patents granted thus far in year $t$; $C I T E_{t}=$ Natural $\log$ of the citation stock in year $t$, the total number of citations that a firm's patent stock received thus far (year $t$ ) from other firms' patents; $S I Z E_{t}=\operatorname{Ln}$ (Total assets); $L E V_{t}=$ Total liabilities/Total assets; $R O A_{t}=$ Net income/Total assets; $F I N_{t}=($ Debt financing + Equity financing $) /$ Total assets.

\subsection{Main Results}

Table 2 reports the results for the multivariate test of the hypothesis based on the estimation in Equation (1). As predicted in Hypothesis 1, the results show that the coefficient of PATENTt is insignificantly negative and the coefficient of CITEt is positively significant at the $1 \%$ level $(\mathrm{t}$-stat. $=3.51$ ) (To control for unobservable firm characteristics that potentially affect EPS and AF, we performed a Firm-fixed Effect Estimation. As a result, the outcome from Firm-fixed Effect Estimation is consistent with the main analysis). This may occur because patent counts and patent citations may indicate two different aspects of the R\&D cycle. In short, the results suggest that the number of patent citation is a better indicator of a firm's quality of intellectual property, which enables successful products and sustainable growth by increasing financial performance [35]. 
Table 2. Patent count, patent citations, and future business performance.

\begin{tabular}{|c|c|c|c|}
\hline \multicolumn{4}{|c|}{$E P S_{t+1}=\alpha_{0}+\beta_{1} A F_{t}^{t+1}+\beta_{2} A F E_{t}+\beta_{3} P A T E N T_{t}+\beta_{4} C I T E_{t}+\beta_{5} G D P_{t}+v_{t}$} \\
\hline Variables & Coeff. & t-Stat. & \\
\hline Intercept & -0.187 & -4.53 & $* * *$ \\
\hline$A F_{t}^{t+1}$ & 0.866 & 52.52 & $* * *$ \\
\hline$A F E_{t}$ & -0.032 & -4.48 & $* * *$ \\
\hline PATENT $_{t}$ & -0.008 & -1.47 & \\
\hline $\mathrm{CITE}_{t}$ & 0.016 & 3.51 & $* * *$ \\
\hline$G D P_{t}$ & 0.048 & 5.76 & $* * *$ \\
\hline Industry Dummy & \multicolumn{3}{|c|}{ Included } \\
\hline Adjusted $R^{2}$ & \multicolumn{3}{|c|}{0.61} \\
\hline F-stat. & \multicolumn{3}{|c|}{$327.75 * * *$} \\
\hline Number of observations & \multicolumn{3}{|c|}{4,789} \\
\hline
\end{tabular}

Table 3 shows the results for Hypothesis 2, which addresses the relationships of analysts' incentives to cover firms (COVER) with patent counts and patent citations. Previous studies have reported that analysts are more likely to follow firms with higher profitability [35,37]. As long as investors demand information on patent-rich firms and expected benefits from following firms with patents are positive, analysts have incentives to cover such firms. According to the results (Since the VIF values of each variable were shown to be less than 10, the multicollinearity between the patent counts and the patent citations was found to have no significant impact on the results of this study. The authors subsequently identified the VIF values for all analyses and found that there was no significant effect of multicollinearity in all models), the coefficient of $P A T E N T_{t}$ is significantly positive at the $10 \%$ level, indicating that firms with patent counts partially offer analysts with incentives to cover those firms. However, the coefficient of $C I T E_{t}$ is positive and significant at the $5 \%$ level, suggesting that firms with more patent citations have larger analyst followings (The results from Firm-fixed Effect Estimation are similar with the main analysis). These results provide support for Hypothesis 2 . Consistent with the findings of previous studies, the coefficient for total assets (SIZE) is positive, implying that the larger the firm, the more likely it is to be followed by analysts [39]. The coefficient for business performance $(R O A)$ is positive, and that for GDP is significantly negative [73].

Table 3. Patent count, patent citations, and analyst following.

\begin{tabular}{|c|c|c|c|c|}
\hline \multicolumn{5}{|c|}{$\operatorname{COVER}_{t}=\alpha_{0}+\beta_{1} P A T E N T_{t}+\beta_{2}$ CITE $_{t}+\beta_{3} S_{I Z E_{t}}+\beta_{4} L E V_{t}+\beta_{5} R O A_{t}+\beta_{6} F I N_{t}+\beta_{6} G D P_{t}+\varepsilon_{t}$} \\
\hline \multirow{2}{*}{$\begin{array}{l}\text { Variables } \\
\text { Intercept }\end{array}$} & \multirow{2}{*}{$\begin{array}{c}\text { Pred. } \\
\text { Sign } \\
+/-\end{array}$} & \multirow{2}{*}{$\begin{array}{l}\text { Coeff. } \\
-0.457\end{array}$} & \multicolumn{2}{|c|}{ t-Stat. } \\
\hline & & & -5.04 & $* * *$ \\
\hline PATENT $_{t}$ & $+/-$ & 0.013 & 1.75 & * \\
\hline$C I T E_{t}$ & $+/-$ & 0.012 & 2.04 & ** \\
\hline$S I Z E_{t}$ & + & 0.279 & 23.07 & $* * *$ \\
\hline$L E V_{t}$ & - & -0.600 & -7.15 & $* * *$ \\
\hline$R O A_{t}$ & $+/-$ & 0.327 & 1.54 & \\
\hline$F I N_{t}$ & - & -0.283 & -2.11 & $* *$ \\
\hline$G D P_{t}$ & $+/-$ & -0.043 & -4.85 & $* *$ \\
\hline Industry Dummy & N/A & \multicolumn{3}{|c|}{ Included } \\
\hline \multicolumn{2}{|c|}{ Adjusted $R^{2}$} & \multicolumn{3}{|c|}{0.28} \\
\hline \multicolumn{2}{|c|}{ F-stat. } & \multicolumn{3}{|c|}{$328.12 * * *$} \\
\hline \multicolumn{2}{|c|}{ Number of observations } & \multicolumn{3}{|c|}{4,091} \\
\hline
\end{tabular}


In sum, the results of patent citations on analyst following provide support for the notion that analysts are more likely to follow firms with high-quality patents and are consistent with the prediction of an increase in demand for analyst services as well as an increase in benefits to analysts from following firms with more patent citations, highlighting patent citations as an important indicator of firm's intellectual property $[37,46,78]$.

Hypothesis 3a posits that how analysts make reports of earnings forecasts for firms with patent counts and patent citations. In Table 4, both of patents and patent citations show a strong association with analysts' forecasts in year $t+1$ but the coefficients of $P A T E N T_{t}$ and CITE $E_{t}$ show the opposite direction with analysts' forecasts in year $t+1$. More specifically, the coefficient on $P A T E N T_{t}$ of -0.005 is negative, and the coefficient on $\mathrm{CITE}_{t}$ of 0.008 is positive and significant at the $5 \%$ level (We performed a Firm-fixed Effect Estimation to control for unobservable firm characteristics that potentially affect EPS and AF and the results are analogous with the main analysis), which suggests that the degree to which firms incorporate the value of patents in earnings is increasing in the degree of citing the patents and provides support for H3a.

Table 4. Patent count, patent citations, and the valuation of analyst.

\begin{tabular}{cccc}
\cline { 2 - 4 }$A F_{t+1}^{t+1}=\alpha_{0}+\beta_{1} A F_{t}^{t+1}+\beta_{2} A F E_{t}+\beta_{3} P A T E N T_{t}+\beta_{4} C I T E_{t}+\beta_{5} G D P_{t}+v_{t}$ \\
\hline Variables & Coeff. & t-Stat. \\
\hline Intercept & -0.140 & -4.58 & $* * *$ \\
$A F_{t}^{t+1}$ & 0.902 & 74.58 & $* * *$ \\
$A F E_{t}$ & -0.026 & -4.02 & $* * *$ \\
$P A T E N T_{t}$ & -0.005 & -1.26 & $* * *$ \\
$C I T E_{t}$ & 0.008 & 2.51 & $* .50$ \\
GDP $P_{t}$ & 0.037 & Included & \\
Industry Dummy & \multicolumn{4}{c}{0.75} \\
Adjusted $R^{2}$ & $932.29 * * *$ \\
F-stat. & 4,789 \\
\hline Number of observations
\end{tabular}

$(1)^{*}, * *$, and ${ }^{* * *}$ indicate significance at the $10 \%, 5 \%$, and $1 \%$ levels, respectively; (2) See Table 1 for variable definitions.

Table 5 shows the results for Hypothesis $3 b$, which addresses whether analysts rationally price the implication that patent counts and patent citations influence future earnings. Several studies have shown that analysts do not fully incorporate implications of accounting information into their earnings forecasts, raising the question of analysts' ability to aid investors in assessing firms [55,56]. Barth and Hutton [79] also report that analysts cannot take the persistence of earnings into account when revising earnings forecasts. The above discussion raises the possibility that analysts' forecasts do not fully incorporate contributions of patent counts and patent citations to future earnings.

Table 5. Patent count, patent citations, and the under-valuation of analyst.

\begin{tabular}{|c|c|c|c|c|c|c|c|}
\hline \multicolumn{8}{|c|}{$\begin{array}{l}A F_{t+1}^{t+1}=\alpha_{0}+\beta_{1} A F_{t}^{t+1}+\beta_{2} A F E_{t}+\beta_{3} P A T E N T_{t}+\beta_{4} C I T E_{t}+\beta_{5} G D P_{t}+v_{t} \\
E_{t+1}=\alpha_{0}^{*}+\beta_{1}^{*} A F_{t}^{t+1}+\beta_{2}^{*} A F E_{t}+\beta_{3}^{*} P A T E N T_{t}+\beta_{4}^{*} C I T E_{t}+\beta_{5} G D P_{t}+\varepsilon_{t}\end{array}$} \\
\hline \multirow[t]{2}{*}{ Variables } & \multicolumn{3}{|c|}{$\begin{array}{c}A F_{t+1}^{t+1} \\
\text { (Forecasting Equation) }\end{array}$} & \multicolumn{3}{|c|}{$\begin{array}{c}E P S_{t+1} \\
\text { (Earnings Equation) }\end{array}$} & \multirow[t]{2}{*}{ Difference } \\
\hline & Coeff. & \multicolumn{2}{|c|}{ t-Stat. } & Coeff. & \multicolumn{2}{|c|}{ t-Stat. } & \\
\hline Intercept & -0.140 & -3.51 & $* * *$ & -0.186 & -3.46 & $* * *$ & \\
\hline$A F_{t}^{t+1}$ & 0.902 & 114.57 & $* * *$ & 0.866 & 81.12 & $* * *$ & \\
\hline$A F E_{t}$ & -0.026 & -5.00 & $* * *$ & -0.032 & -4.56 & $* * *$ & \\
\hline PATENT $_{t}$ & -0.005 & -1.16 & & -0.008 & -1.35 & & 1.56 \\
\hline $\mathrm{CITE}_{t}$ & 0.008 & 2.42 & $* *$ & 0.016 & 3.34 & $* * *$ & $15.64 * * *$ \\
\hline$G D P_{t}$ & 0.037 & 5.90 & $* * *$ & 0.048 & 5.68 & $* * *$ & \\
\hline Adjusted $R^{2}$ & \multicolumn{3}{|c|}{0.75} & \multicolumn{3}{|c|}{0.61} & \\
\hline F-stat. & \multicolumn{3}{|c|}{$408.28^{* * *}$} & \multicolumn{3}{|c|}{$372.41 * * *$} & \\
\hline Number of observations & \multicolumn{3}{|c|}{4,789} & \multicolumn{3}{|c|}{4,789} & \\
\hline
\end{tabular}

$(1)^{*}, * *$, and $* * *$ indicate significance at the $10 \%, 5 \%$, and $1 \%$ levels, respectively; (2) See Table 1 for variable definitions. 
First, Table 5 reports that $A F_{t+1}^{t+1}$ is positively related to $A F_{t}^{t+1}$. This provides support for the specification assuming that analysts' post-announcement forecasts are conditional on their past forecasts. The analyst forecast error $A F E_{t}$ has a negative effect on analysts' post-announcement forecasts. The negative coefficient of PATENT $t$ may imply that earnings of firms with rich patent counts reduce their future earnings and that analysts are likely to reduce their post-announcement forecasts but it is not significant. In other words, patent counts may not be a good indicator of a firm's innovation capability because it is a noisy measure of a firm's innovation. That is, patent counts may not contribute to a future financial performance $[4,5]$.

As for our main variable of interest, $C I T E_{t}, \beta_{4}$ and $\beta_{4}^{*}$ are positive and significant in each equation, implying that patent citations are an important indicator of future profitability and that the higher the patent citations, the more likely the analyst is to elevate the earnings forecast. However, the results indicate mis-valuation in patent citations, as shown in the last column of Table 6 ( $p$-value $=15.64$ for the null hypothesis $\left.\beta_{4}=\beta_{4}^{*}\right)$. More specifically, the coefficient of $C I T E_{t}\left(\beta_{4}\right)$ in the forecasting equation is 0.008 , whereas that in the earnings equation is 0.016 , which implies analysts' under-valuation.

Table 6. Long-term forecasting window.

\begin{tabular}{|c|c|c|c|c|c|}
\hline Panel A. H1 & & & & & \\
\hline Variables & Coeff. & t-Stat. & & & \\
\hline Intercept & -0.141 & $-3.19 * * *$ & & & \\
\hline PATENT $_{t}$ & -0.005 & -1.21 & & & \\
\hline$C I T E_{t}$ & 0.014 & $3.19^{* * *}$ & & & \\
\hline Controls & \multicolumn{2}{|c|}{ Included } & & & \\
\hline Adjusted $R^{2}$ & \multicolumn{2}{|c|}{0.65} & & & \\
\hline F-stat. & \multicolumn{2}{|c|}{$298.66^{* * *}$} & & & \\
\hline Observations & \multicolumn{2}{|c|}{4,155} & & & \\
\hline \multicolumn{6}{|l|}{ Panel B. H2 } \\
\hline Variables & Coeff. & t-Stat. & & & \\
\hline Intercept & -0.571 & -5.72 & & & \\
\hline PATENTt & -0.004 & -0.48 & & & \\
\hline CITEt & 0.011 & 1.73 * & & & \\
\hline Controls & \multicolumn{2}{|c|}{ Included } & & & \\
\hline Adjusted $R^{2}$ & \multicolumn{2}{|c|}{0.27} & & & \\
\hline F-stat. & \multicolumn{2}{|c|}{$106.4^{* * *}$} & & & \\
\hline Observations & \multicolumn{2}{|c|}{3,588} & & & \\
\hline \multicolumn{6}{|l|}{ Panel C. H3a } \\
\hline Variables & Coeff. & t-Stat. & & & \\
\hline Intercept & -0.117 & $-3.59 * * *$ & & & \\
\hline PATENT $_{t}$ & -0.003 & -0.98 & & & \\
\hline $\mathrm{CITE}_{t}$ & 0.008 & $2.33^{* *}$ & & & \\
\hline Controls & \multicolumn{2}{|c|}{ Included } & & & \\
\hline Adjusted $R^{2}$ & \multicolumn{2}{|c|}{0.76} & & & \\
\hline F-stat. & \multicolumn{2}{|c|}{$559.62 * * *$} & & & \\
\hline Observations & \multicolumn{2}{|c|}{4,155} & & & \\
\hline \multicolumn{6}{|l|}{ Panel D. H3b } \\
\hline Variables & Coeff. & t-Stat. & Coeff. & t-Stat. & Difference \\
\hline Intercept & -0.117 & $-2.72 * * *$ & -0.141 & $-2.44^{* *}$ & \\
\hline PATENT $_{t}$ & -0.003 & -0.91 & -0.005 & -1.10 & 1.19 \\
\hline$C I T E_{t}$ & 0.008 & $2.18^{* *}$ & 0.014 & $2.92 * * *$ & $11.34^{* * *}$ \\
\hline Controls & \multicolumn{2}{|c|}{ Included } & \multicolumn{2}{|c|}{ Included } & \\
\hline Adjusted $R^{2}$ & \multicolumn{2}{|c|}{0.76} & \multicolumn{2}{|c|}{0.62} & \\
\hline F-stat. & \multicolumn{2}{|c|}{$376.07^{* * *}$} & \multicolumn{2}{|c|}{$193.48^{* * *}$} & \\
\hline Observations & \multicolumn{2}{|c|}{4,155} & \multicolumn{2}{|c|}{4,155} & \\
\hline
\end{tabular}


These results suggest that analysts positively evaluate $C I T E_{t}$, although their downward or upward revisions do not impact subsequent earnings. This may be because analysts cannot reflect patent citations in future profitability because they cannot accurately discriminate the effect on firms' future earnings that patent citations have. In other words, Table 5 indicates that analysts tend to make positive forecasts for firms with patent citations but undervalue the importance of them.

In summary, the results provide support for Hypothesis $3 \mathrm{~b}$ and the notion that even analysts, the so-called sophisticated investors, cannot reflect the precise impact of patent counts and patent citations. Given that the financial market is an important source of consistent support for R\&D investment, careful analyses of analysts' valuation of differential contributions of a firm's strengthened innovation capability to its future earnings are crucial for many knowledge-oriented firms' survivals.

\subsection{Long-Term Forecasting Window}

The regression results in this paper examine the relation between patent citation and business performance, analyst following, and analysts' valuation on quality of intellectual property using a one-year-ahead forecasting window. It would be intriguing to investigate how long patent citations affect future business performance, analyst coverage, and analyst forecasts by creating incremental value. This is because it takes many years from the moment of registering of patents to the moment of making corporate profitability. To investigate these long-term relationships, we now expand the measurement window of all regressions on hypotheses to a two-year-ahead window. By using these variables, we re-estimate the baseline prediction model in main regressions and report the related results in Table 6.

Panel A in Table 6 shows the results of the first hypothesis (H1) implying that patent citation is positively associated with business performance. And Panel B and Panel C of Table 6 report that patent citation is positively related to analyst following $(\mathrm{H} 2)$ and analysts' forecasts (H3a), respectively. Finally, Panel D of Table 6 which shows analysts' valuation on corporate patent activities, finds that all the coefficients on patent citation show the similar direction and significance with the main results $(\mathrm{H} 3 \mathrm{~b})$. Overall, all of the results indicate that the effects of patent activities on corporate business performance, analyst following, and analysts' assessment on the patent-rich firms last for long-term periods.

\section{A Summary and Conclusions}

This study examines the effects of patents on business performance and financial analysts' behavior by partitioning patent information into patent citations and patent counts. According to the results, patent citations are positively related to business performance, whereas patent counts are negatively related to it. In addition, financial analysts are more likely to follow firms with higher patent citations, which is consistent with the notion that the demand for analysts' services and their opportunities to obtain commissions increase for firms' patent citations, resulting in better information environments [80]. Finally, the study also investigates analysts' forecasting activities and evaluates whether analysts correctly incorporate contributions of patent counts and patent citations into their forecasts of future earnings. The results indicate that even though analysts' forecasts for firms with high patent citations show positive value by the effects of patents on innovation capability, analysts' forecasts of future earnings do not fully reflect implications for future earnings of patent-rich firms in the current period. More specifically, firms with higher patent citations show higher future earnings, whereas those with higher patent counts find lower future profitability. In both cases, however, absolute values of coefficients for patent counts and patent citations are lower than their precise impacts, indicating that analysts tend to make mis-valuation. The results suggest that analysts' forecasts do not fully incorporate available information on patents and that a failure in the valuation process can produce misleading inferences.

The study extends the literature on patents and financial analysts' forecasts by documenting that information on patent citations and patent counts is significantly related to both the decision to follow a firm and that to revise a forecast. First, a firm's existing intellectual property may contribute directly 
to the novelty of a new innovation [81]. A successful innovation depends on a firm's technological and strategic knowledge and the market's financial support based on a rational evaluation of the firm's patent activity. The fact that even sophisticated information intermediaries such as analysts cannot fully appreciate such information suggests that market participants tend to mis-forecast patent information. This under-valuation can be an obstacle for patent-rich firms to be supported in a consistent manner by the financial market by impeding the release of sufficient information on those firms.

Second, to the extent the misevaluation of patent-rich firms implies some cost associated with a complex assessment of a firm's innovation capability, the results provide some guidelines for standard-setting bodies in enhancing the precise disclosure of non-GAAP indicators such as patents. Given the empirical results documenting differential responses to patent citations and patent counts, standard-setting bodies should consider requesting firms to report explicit information on how each variable for non-GAAP indicators may map into their future profitability. In this way, patent-rich firms can be assessed based on their intrinsic value to increase financial investment from the stock market.

Finally, analysts' research reports typically contain their forecasts of firms' performance and/or their investment recommendations $[82,83]$. Archival research has shown that analysts' reports are informative for the market $[61,84]$ because such reports are viewed to be timely or have superior contents $[85,86]$. However, this study has limitation in that it only addressed the aspects of earnings forecasts and did not consider psychological effects (herding, framing effect) and the problem of self-fulfilling stock recommendations. Nevertheless, the results provide some insights for analysts by pointing out their forecasting accuracy on patent information. These insights are expected to help analysts tailor or develop the quality of their reports such that the precision of information in their reports can be better aligned with their investors to enhance the usefulness of those reports.

Author Contributions: Conceptualization, J.G. and W.H.; methodology, J.G. and W.H.; software, J.G. and W.H.; validation, J.G. and W.H.; formal analysis, Y.J.; investigation, Y.J.; resources, W.H.; data curation, J.G.; writing—original draft preparation, J.L.; writing—review and editing, J.L.; supervision, J.G., W.H., J.L., and Y.J.

Funding: This research received no external funding.

Conflicts of Interest: The authors declare no conflict of interest.

\section{References}

1. Deng, Z.; Lev, B.; Narin, F. Science and technology as predictors of stock performance. Financ. Anal. J. 1999, 55, 20-32. [CrossRef]

2. Lanjouw, J.; Schankerman, M. Characteristics of patent litigation: A window on competition. J. Econ. 2001, 32, 129-151. [CrossRef]

3. Traitenberg, M. The welfare analysis of product innovations with an application to computed tomography scanners. J. Political Econ. 1989, 97, 445-479. [CrossRef]

4. Trajtenberg, M. A penny for your quotes: Patent citations and the value of innovations. Rand J. Econ. 1990, 21, 172-187. [CrossRef]

5. Hall, H.B.; Jaffe, A.; Trajtenberg, M. Market value and patent citations. Rand J. Econ. 2005, 36, 16-38.

6. Hirshleifer, D.; Hsu, P.H.; Li, D. Innovative efficiency and stock returns. J. Financ. Econ. 2013, 107, 632-654. [CrossRef]

7. Nelson, R.R.; Winter, S.G. An Evolutionary Theory of Economic Change; Belknap Press of Harvard University Press: Cambridge, MA, USA, 1982.

8. Brown, J.R.; Petersen, B.C. Why has the investment-cash flow sensitivity declined so sharply? Rising R\&D and equity market developments. J. Bank. Financ. 2009, 33, 971-984.

9. Amir, E.; Lev, B. Value-relevance of nonfinancial information: The wireless communication industry. J. Account. Econ. 1996, 22, 3-30. [CrossRef]

10. Behn, B.K. Value implications of unfilled order backlogs. Adv. Account. 1996, 14, 61-84.

11. Ittner, C.; Larcker, D. Are nonfinancial measures leading indicators of financial performance? An analysis of customer satisfaction. J. Account. Res. 1998, 36, 1-36. [CrossRef] 
12. Trueman, B.; Wong, F.; Zhang, X. The eyeballs have it: Searching for the value in internet stocks. J. Account. Res. 2001, 38, 137-162. [CrossRef]

13. Rajgopal, S.; Venkatachalam, M.; Kotha, S. The value relevance of network advantages: The case of e-commerce firms. J. Account. Res. 2003, 41, 135-162. [CrossRef]

14. Rajgopal, S.; Venkatachalam, M.; Kotha, S. Managerial actions stock returns and accounting earnings: The case of business-to-business internet firms. J. Account. Res. 2002, 40, 529-556. [CrossRef]

15. Cockburn, I.; Griliches, Z. Industry effects and appropriability measures in the stock market's valuation of R\&D and patents. Am. Econ. Rev. 1988, 78, 419-423.

16. Acs, Z.J.; Audretsch, D.B. Patents as a measure of innovative activity. Kyklos 1989, 42, 171-180. [CrossRef]

17. Napolitano, G.; Sirilli, G. The patent system and the exploitation of inventions: Results of a statistical survey conducted in Italy. Technovation 1990, 10, 5-16. [CrossRef]

18. Cantwell John, A.; Hodson, C. Global RED and UK competitiveness. Global Research Strategy and International Competitiveness; Basil Blackwell: Oxford, UK, 1991.

19. Patel, P.; Pavitt, K. Patterns of technological activity: Their measurement and interpretation. In Handbook of the Economics of Innovations and Technological Change; Stoneman, P., Ed.; Blackwell: Cambridge, MA, USA, 1995; pp. 14-51.

20. Freeman, C.; Soete, L. The Economics of Industrial Innovation, 3rd ed.; MIT Press: Cambridge, MA, USA, 1997.

21. Griliches, Z. Patent Statistics as Economic Indicators: A Survey; University of Chicago Press: Chicago, IL, USA, 1998; pp. 287-343.

22. Bresman, J.; Birkinshaw, J.; Nobel, R. Knowledge transfer in international acquisitions. J. Int. Bus. Stud. 1999, 30, 439-462. [CrossRef]

23. Cohen, W.M.; Levin, R. Empirical studies of innovation and market structure. In Handbook of Industrial Organization; Schmalensee, R., Willig, R., Eds.; Elsevier: Amsterdam, The Netherlands, 1989.

24. Dosi, G. Technological paradigms and technological trajectories. Res. Policy 1982, 11, 147-162. [CrossRef]

25. Archibugi, D. Patenting as an indicator of technological innovation: A review. Sci. Public Policy 1992, 19, 357-368.

26. Harhoff, D.; Narin, F.; Scherer, F.M.; Vopel, K. Citation frequency and the value of patented inventions. Rev. Econ. Stat. 1999, 81, 511-515. [CrossRef]

27. Scherer, F.M. Corporate inventive output profits, and growth. J. Political Econ. 1965, 73, 290-297. [CrossRef]

28. Hu, D.; Chen, H.; Huang, Z.; Roco, M.C. Longitudinal study on patent citations to academic research articles in nanotechnology (1997-2004). J. Nanoparticle Res. 2007, 9, 529-542. [CrossRef]

29. Criscuoloa, P.; Verspagen, B. Does it matter where patent citations come from? Inventor vs. examiner citations in European patents. Res. Policy 2008, 37, 1892-1908. [CrossRef]

30. Ribeiro, L.C.; Ruiz, R.M.; Bernardes, A.T.; Albuquerque, E.M. Matrices of science and technology interactions and patterns of structured growth: Implications for development. Scientometrics 2010, 83, 55-75. [CrossRef]

31. Callaert, J.; Grouwels, J.; Looy, B.V. Delineating the scientific footprint in technology: Identifying scientific publications within non-patent references. Scientometrics 2012, 91, 383-398. [CrossRef]

32. Albert, M.B.; Avery, D.; Narin, F.; McAllister, P. Direct validation of citation counts as indicators of industrially important patents. Res. Policy 1991, 20, 251-259. [CrossRef]

33. Bresnahan, T. Post-entry competition in the plain paper copier market. Am. Econ. Rev. 1985, 75, 15-19.

34. Narin, F.; Noma, E.; Perry, R. Patents as indicators of corporate technological strength. Res. Policy 1987, 16, 143-155. [CrossRef]

35. Gu, F. Innovation future earnings, and market efficiency. J. Account. Audit. Financ. 2005, 20, 385-418. [CrossRef]

36. Han, S.; Jin, T.K.; Lobo, G. Managerial ownership and financial analysts' information environment. J. Bus. Financ. Account. 2014, 41, 328-362. [CrossRef]

37. Bhushan, R. Firm characteristics and analyst following. J. Account. Econ. 1989, 11, 255-274. [CrossRef]

38. Bhushan, R.; O’Brien, P.C. Analyst following and institutional ownership. J. Account. Res. 1990, $28,55-76$.

39. Lang, M.; Lundholm, R. Corporate disclosure policy and analyst behavior. Account. Rev. 1996, 71, 467-492.

40. Bushman, R.; Piotroski, J.; Smith, A. What determines corporate transparency? J. Account. Res. 2004, 42, 207-252. [CrossRef]

41. Niehaus, G.; Zhang, D.H. The impact of sell-side analyst research coverage on an affiliated broker's market share of trading volume. SSRN Electron. J. 2010, 34, 776-787. [CrossRef] 
42. McNichols, M.; O’Brien, P.C. Self-selection and analyst coverage. J. Account. Res. 1997, 35, 167-199. [CrossRef]

43. Penman, S.H. An evaluation of accounting rates-of-return. J. Account. Audit. Financ. 1991, 6, $233-255$. [CrossRef]

44. Penman, S.H. Financial Statement Analysis and Security Valuation, 4th ed.; McGraw-Hill Irwin: New York, NY, USA, 2010.

45. Ajinkya, B.; Gift, M. Dispersion of financial analysts' earnings forecasts and the (option model) implied standard deviations of stock returns. J. Financ. 1985, 40, 1353-1365. [CrossRef]

46. Barth, E.M.; Kasznik, R.; McNichols, M.F. Analyst coverage and intangible assets. J. Account. Res. 2001, 39, 1-34. [CrossRef]

47. Barron, O.E.; Byard, C.K.; Riedl, E.J. High-technology intangibles and analysts' forecasts. J. Account. Res. 2002, 40, 289-312. [CrossRef]

48. Ciftci, M.; Darrough, M. What explains the valuation difference between intangible-intensive profit and loss firms? J. Bus. Financ. Account. 2015, 42, 138-166. [CrossRef]

49. Datta, S.; Iskandar-Datta, M.; Sharma, V. Product market pricing power industry concentration and analysts' earnings forecasts. J. Bank. Financ. 2011, 35, 1352-1366. [CrossRef]

50. Palmon, D.; Yezegel, A. R\&D intensity and the value of analysts' recommendations. Contemp. Account. Res. 2012, 29, 621-654.

51. Cohen, L.; Diether, K.; Malloy, C. Misvaluing innovation. Rev. Financ. Stud. 2013, 26, 635-666. [CrossRef]

52. Hirshleifer, D.A.; Hsu, P.H.; Li, D. Innovative originality profitability, and stock returns. Rev. Financ. Stud. 2018, 31, 2553-2605. [CrossRef]

53. Sloan, R.G. Do stock prices fully reflect information in accruals and cash flows? Account. Rev. 1996, 71, 289-315.

54. Xie, H. The mispricing of abnormal accruals. Account. Rev. 2001, 76, 357-373. [CrossRef]

55. Stober, T. Summary financial statement measures and analysts' forecast of earnings. J. Account. Econ. 1992, 15, 347-372. [CrossRef]

56. Abarbanell, J.; Bushee, B. Fundamental analysis future earnings, and stock price. J. Account. Res. 1997, 35, 1-24. [CrossRef]

57. O'Brien, P. Analysts forecasts as earnings expectations. J. Account. Econ. 1988, 10, 53-83. [CrossRef]

58. Ali, A.; Klein, A.; Rosenfeld, J. Analysts' use of information about permanent and transitory earnings components in forecasting annual EPS. Account. Rev. 1992, 67, 183-198.

59. Amir, E.; Lev, B.; Sougiannis, T. Do financial analysts get intangibles? Eur. Account. Rev. 2003, 12, 635-659. [CrossRef]

60. Gu, F.; Wang, W. Intangible assets information complexity, and analysts' earnings forecasts. J. Bus. Financ. Account. 2005, 32, 1673-1702. [CrossRef]

61. Lys, T.; Sohn, S. The association between revisions of financial analysts' earnings forecasts and security-price changes. J. Account. Econ. 1990, 13, 341-363. [CrossRef]

62. Abarbanell, J.S. Do analysts' earnings forecasts incorporate information in prior stock price changes? J. Account. Econ. 1991, 14, 147-165. [CrossRef]

63. Griliches, Z. Market value R\&D and patents. Econ. Lett. 1981, 7, 183-187.

64. Lev, B. Intangibles: Management Measurement, and Reporting; Brookings Institution Press: Washington, DC, USA, 2001.

65. Lev, B.; Sougiannis, T. The capitalization amortization, and value-relevance of R\&D. J. Account. Econ. 1996, 21, 107-138.

66. Jones, D. Voluntary disclosure in R\&D-intensive industries. Contemp. Account. Res. 2007, 24, 489-522.

67. Bhattacharya, S.; Ritter, J.R. Innovation and communication: Signaling with partial disclosure. Rev. Econ. Stud. 1983, 50, 331-346. [CrossRef]

68. Anton, J.J.; Yao, D.A. The sale of ideas: Strategic disclosure property rights, and contracting. Rev. Econ. Stud. 2002, 69, 513-531. [CrossRef]

69. Brown, S.; Hillegeist, S. How disclosure quality affects the level of information asymmetry. Rev. Account. Stud. 2007, 12, 443-477. [CrossRef]

70. Pertersen, M.A. Estimating Standard Errors in Finance Panel Data Sets: Comparing Approaches. The Rev. of Fin. Stud. 2009, 22, 435-480. [CrossRef] 
71. Mishkin, F. A Rational Expectations Approach to Macroeconometrics: Testing Policy Effectiveness and Efficient-Market Models; University of Chicago Press: Chicago, IL, USA, 2007.

72. Kasznik, R.; McNichols, M.F. Does meeting earnings expectations matter? Evidence from analyst forecast revisions and share prices. J. Account. Res. 2002, 40, 727-759. [CrossRef]

73. Yu, F. Analyst coverage and earnings management. J. Financ. Econ. 2008, 88, 245-271. [CrossRef]

74. Kasznik, R. On the association between voluntary disclosure and earnings management. J. Account. Res. 1999, 37, 57-81. [CrossRef]

75. Dechow, M.P.; Dichev, I. The quality of accruals and earnings: The role of accrual estimation errors. Account. Rev. 2002, 77, 35-59. [CrossRef]

76. Irvine, P.J. Do analysts generate trade for their firms? Evidence from the Toronto stock exchange. J. Account. Econ. 2001, 30, 209-226. [CrossRef]

77. Eddy, A.; Seifert, B. An examination of hypotheses concerning earnings forecast errors. Q. J. Bus. Econ. 1992, 31, 22-37.

78. Lobo, G.J.; Song, M.; Stanford, M. Accruals quality and analyst coverage. J. Bank. Financ. 2012, 36, 497-508. [CrossRef]

79. Barth, M.; Hutton, A. Analyst earnings forecast revisions and the pricing of accruals. Rev. Account. Stud. 2004, 9, 59-96. [CrossRef]

80. Dugar, A.; Nathan, S. The effect of investment banking relationship on financial analysts' earnings forecasts and investment recommendations. Contemp. Account. Res. 1995, 12, 131-160. [CrossRef]

81. Lee, C.Y. A theory of firm growth: Learning capability knowledge threshold, and patterns of growth. Res. Policy 2010, 39, 278-289. [CrossRef]

82. Frankel, R.; Li, X. Characteristics of a firm's information environment and the information asymmetry between insiders and outsiders. J. Account. Econ. 2004, 37, 229-259. [CrossRef]

83. Hirst, D.E.; Koonce, L.; Simko, P.J. Investor reactions to financial analysts' research reports. J. Account. Res. 1995, 33, 335-351. [CrossRef]

84. Givoly, D.; Lakonishok, J. The information content of financial analysts' forecasts of earnings: Some evidence on semi-strong inefficiency. J. Account. Econ. 1979, 1, 165-185. [CrossRef]

85. Francis, J.; Schipper, K.; Vincent, L. Earnings announcements and competing information. J. Account. Econ. 2002, 33, 313-342. [CrossRef]

86. Chang, M.; Ng, J.; Yu, K. The influence of analyst and management forecasts on investors' decision making: An experimental approach. Aust. J. Manag. 2008, 33, 47-67. [CrossRef] 